Warszawskie Studia Pastoralne

UKSW

Rok XII 2017 Nr 2(35)

Ks. Edmund Robek SAC

\title{
Recenzja książki: ks. Mirosław Mejzner SAC, Wędrówki ku sacrum, Apostolicum, Warszawa 2017, ss. 380.
}

Z życiorysu ks. Mirosława Mejznera SAC wynika, że jest on teologiem i patrologiem. Umiejętności nabyte podczas lat studiów Autor wykorzystywał w pracy badawczej, dydaktyce oraz w przygotowanych publikacjach naukowych. W swojej najnowszej książce zastosował metodę historyczno-teologiczną i wykorzystał wiedzę opartą na szerokim doświadczeniu podróżniczym (jest przewodnikiem pielgrzymkowym).

W omawianej publikacji Autor zajął się tematyką związaną z miejscami świętymi. Nie ograniczył się jednak do prezentacji samych miejsc, ale ukazał na ich tle konkretne osoby, będące świadkami wydarzeń mających trwałe znaczenie dla chrześcijańskiej wiary i jej pogłębienia.

Książka składa się z dziewięciu rozdziałów: 1) Pielgrzymowanie, 2) Jezus Chrystus, 3) Maryja, 4) Apostołowie, 5) Święty Wincenty Pallotti i jego dzieła, 6) Święty Jan Paweł II, 7) Biblia i kultura, 8) Historia i pamięć, 9) Miejsca święte. Ponadto zamieszczone są: Przedmowa, Wstęp, Posłowie, Summary, Bibliografia oraz Nota o Autorze.

Analizując strukturę publikacji można stwierdzić, że choć paleta poruszanych w książce problemów jest bardzo urozmaicona, to widać w nich wyraźny zamysł merytoryczny i funkcjonalny wobec tematu pracy. Już przy zapoznawaniu się ze spisem treści pozytywnie nastawia Czytelnika do jej lektury „lekkość” stosowanych terminów przy zachowaniu ich naukowego znaczenia. Zastosowana intytulacja zachęca do zapoznania się z treścią wydzielonych w publikacji szczegółowych zagadnień.

We wstępie Autor zaznacza, że jego publikacja „Wędrówki ku sacrum” jest zasadniczo zbiorem wcześniejszych przemyśleń i studiów 
o tematyce teologicznej, historycznej, kulturowej oraz z dziedziny turystyki religijnej. To dzieło o chrześcijańskim pielgrzymowaniu, którego rozdziały są typowo teologiczne i mają charakter historyczno-zbawczy.

W pierwszym rozdziale Autor wyraźnie rozróżnia turystykę społeczno-kulturową od religijnej oraz od pielgrzymowania. Odwołuje się do Nowego Testamentu, ukazującego Jezusa w nieustannym ruchu we wszystkich okresach jego życia. Ten dynamizm zaszczepił także swoim Apostołom: Idźcie więc i nauczajcie wszystkie narody. Rzeczywistość pielgrzymowania biblijnego Autor ujął w trzech podstawowych punktach: 1) wędrówka człowieka od bram raju do Ojca Jezusa Chrystusa; 2) przemieszczanie się w przestrzeni i czasie, by poznać Boga; 3) Boże towarzyszenie człowiekowi na wszystkich jego drogach.

Rozdział drugi przedstawia ziemskie losy Jezusa z Nazaretu w oparciu o historyczny opis wydarzeń zawarty w Ewangeliach. Autor z nieprzeciętną sprawnością ukazuje (czasami zdumiewająco, a czasami wstrząsająco) dzieło Chrystusa jako Zbawiciela świata. Czyni to po mistrzowsku, w sposób plastyczny i wielowątkowy. Wszystko zaś to umieszcza na tle ówczesnych realiów panujących na Bliskim Wschodzie.

Trzeci rozdział poświęcony jest osobie Maryi. W oparciu o Pismo Święte, pisma Ojców Kościoła, dokumenty Kościoła, zwłaszcza Sobór Watykański II, oraz objawienia maryjne przedstawia Maryję jako Matkę Chrystusa. Omawiając Jej niepokalane poczęcie i wniebowzięcie, Autor nawiązuje jednocześnie do ostatnich, nieznanych wcześniej, form poczęcia człowieka (in vitro) oraz jego uśmiercania poprzez aborcję. Najdramatyczniejszym momentem w życiu Maryi była oczywiście męka Jej syna Jezusa. Chrześcijańska tradycja przeznaczyła dla Niej stałe miejsce na via Crucis (drodze Krzyżowej). Ewangelia Janowa mówi o tym, że stała pod krzyżem, z horyzontu którego Syn oddał Ją pod opiekę Janowi. Wtedy właśnie stała się Matką Kościoła, Matką Nowego Ludu Bożego, którego symbolicznym reprezentantem był umiłowany Uczeń.

Czwarty rozdział poświęcił Autor Apostołom. Nie rozpoczął go od powołania ich przez Jezusa, ale od męczeństwa św. Pawła. 
Apostołowie zostali przedstawieni jako bohaterowie, obdarzeni mocą, którzy słowem ewangelizowali ludzi - całe narody kierując ku Bogu, aż w końcu ściągnęli na siebie nienawiść panujących i ponieśli śmierć męczeńską (oprócz Jana, który umarł śmiercią naturalną).

Treścią rozdziału piątego jest prezentacja Wincentego Pallottiego i jego dzieł: Stowarzyszenia Apostolstwa Katolickiego i Zjednoczenia Apostolstwa Katolickiego. Kapłan ten i jego dziedzictwo są szczególnie bliskie Autorowi, bowiem żyje on we wspólnocie pallotyńskiej.

Wincenty Pallotti żył w pierwszej połowie XIX w. w Rzymie, w ostatnich dziesięcioleciach istnienia Państwa Kościelnego. W ciągu pięćdziesięciu pięciu lat jego życia na tamtym terenie miały miejsce 4 rewolucje oraz okupacja napoleońska. Był to także okres wielkich zmian w Kościele katolickim: rozwoju misji zagranicznych, docenienia roli duszpasterstwa i katechezy, powstania nowych zakonów, a także budzenia się samoświadomości ludzi świeckich w Kościele. Do tego ostatniego czynnie przyczynił się właśnie W. Pallotti, który z jednej strony był człowiekiem swej epoki, a z drugiej kapłanem wypełnionym wiarą i nadzieją. Poprzez swoje dzieła jest on znany na całym świecie.

W rozdziale szóstym Autor przybliża Czytelnikom postać św. Jana Pawła II, miedzy innymi jako pielgrzyma, oraz jego nauczanie. Był on papieżem naszych czasów, dlatego jego nauczanie i wskazówki życia są tak cenne dla współczesnego Czytelnika. Wiele miejsca Autor poświęcił papieskim pielgrzymkom do Polski oraz takim problemom, jak: zagadnienie wolności religijnej czy prawa człowieka.

Nieznajomość pism - dokumentów Kościoła, a przede wszystkim Pisma Świętego (zarówno Starego, jak i Nowego Testamentu) jest nieznajomością Chrystusa. Tę starożytną maksymę przywołuje Autor w siódmym rozdziale, a następnie ukazuje jeszcze inne źródła mówiące o Chrystusie i chrześcijaństwie. Rozdział ten kończy kult Chrystusa i pobożność ludowa.

W rozdziale ósmym Autor przechodzi do historii i pamięci. Przywołuje tragiczną historię hitlerowskiego obozu śmierci Auschwitz-Birkenau, cmentarze wojskowe w Katyniu, Miednoje i Charkowie. 
A cały ten rozdział kończy wierszem ks. Jana Twardowskiego: „Śpieszmy się kochać ludzi, tak szybko odchodzą...”

W dziewiątym, ostatnim rozdziale Autor ukazuje miejsca święte, do których ciągle ludzie pielgrzymują, a które od wieków są związane z dziełem naszego zbawienia: Nazaret - zwiastowanie Maryi, Betlejem - narodzenie Jezusa, Egipt - ucieczka św. Rodziny przed Herodem, Tars - miasto, z którego wywodzi się św. Paweł, Rzym - Wieczne Miasto - siedziba papieży, Asyż - miasto modlitwy o pokój. Autor nie ogranicza się jedynie do miejsc historycznych, w których Apostołowie głosili Ewangelię a słuchacze przyjmowali chrzest, ale wprowadza Czytelnika do miejsc, do których ludność z Polski wędrowała w XX wieku za chlebem, zabierając ze sobą chrześcijaństwo (np. do Ameryki).

Zapraszając do „wędrówki ku sacrum”, Autor wskazuje Czytelnikowi także miejsca związane z wydarzeniami w Polsce: polskie Tatry z giewontowskim krzyżem, Sieradz związany z Bractwem Rycerskim Ziemi Sieradzkiej słynnym z Bitwy pod Grunwaldem, Zduńską Wolę z kultem bł. Maksymilianem Kolbe, Swarzewo z królującą Matką Bożą Królową Morza i wiele innych.

Po zapoznaniu się z całością pracy, można z całą pewnością stwierdzić, że Autor posiada odpowiednią wiedzę metodologiczną, którą potrafił zastosować w praktyce. Świadczy o tym przede wszystkim dokładnie przeprowadzona kwerenda naukowa, której efektem jest dobrze wyselekcjonowany spis bibliograficzny. Autor skategoryzował zebraną bibliografię, po uprzednim zapoznaniu się z merytoryczną zawartością zebranych źródeł i publikacji. O dogłębnej znajomości problemu „wędrowania ku sacrum” świadczy logicznie ułożony plan książki.

Ks. Mirosław Mejzner SAC podjął temat, który naukowo został rozpracowany w różnych aspektach. Mogłoby się wydawać, że o pielgrzymowaniu do miejsc świętych nic nowego już powiedzieć nie można. Tymczasem Autor recenzowanej książki przyjął za podstawę swoich badań ważną zasadę stosowaną w teologii pastoralnej, że najlepszą praktyką jest dobra teoria. Autor potraktował zdefiniowanie wędrującego człowieka, jako istoty poszukującej celu i sensu 
życia - homo viator. Niewątpliwą zasługą ks. M. Mejznera jest także zwrócenie uwagi na główne elementy duszpasterskiej posługi Kościoła pielgrzymującego.

W podsumowaniu walorów recenzowanej książki należy stwierdzić, że jej Autor zapracował na miano dojrzałego, samodzielnego i twórczego teologa, patrologa i pastoralisty. Recenzowana książka jest bardzo rzetelnym studium historyczno-teologiczno-pastoralnym. 